Volume 7 Nomor 1 Tahun 2019

Penerapan Pendekatan Saintifik Dengan Media Model dalam Peningkatan Pembelajaran Matematika tentang Bangun Ruang pada Siswa Kelas V SD Negeri 3 Tersobo Tahun Ajaran 2017/2018

\title{
Isnaeni Aprilia Kartikasari ${ }^{1}$, Wahyudi ${ }^{2}$, Tri Saptuti Susiani ${ }^{3}$
}

1,2,3 Universitas Sebelas Maret

aprilkartika218@gmail.com

Article History

accepted 01/02/2019

approved 01/03/2019

published 01/04/2019

\begin{abstract}
The objectives of this research are: (1) to describe the steps on the use of scientific approach using model media, (2) to improve Mathematics learning about geometry for fifth-grade students of SD Negeri 3 Tersobo in the academic year of 2017/2018, 3) to describe problems and solutions on the use of scientific approach using model media inimproving Mathematics learning about geometry for the fifth-grade students of SD Negeri 3 Tersobo in the academic year of 2017/2018. Subjects of the research were 39 students of the fifth-grade of V SD Negeri 3 Tersobo in the academic year of 2017/2018. The conclusion of this research is the use of scientific approach using model media can improve Mathematics about geometryfor the fifthgrade students of SD Negeri 3 Tersobo in the academic year of 2017/2018.
\end{abstract}

Keywords: scientific approach, model media, Mathematics

\section{Abstrak}

Tujuan penelitian ini yaitu: (1) mendeskripsikan langkah penerapan pendekatan saintifik dengan media model, (2) meningkatkan pembelajaran tentang bangun ruang dengan menerapkan pendekatan saintifik dengan media model pada siswa kelas V SD, (3) mendeskripsikan kendala dan solusi dalam penerapan pendekatan saintifik dengan media model. penelitian tindakan kelas (PTK) kolaboratif. Penelitian dilaksanakan selama tiga siklus. Subjek penelitian ini adalah siswa kelas V SD Negeri 3 Tersobo tahun ajaran 2017/2018 yang berjumlah 39 siswa. Kesimpulan penelitian ini menunjukkan bahwa penerapan pendekatan saintifik dengan media model dapat meningkatkan pembelajaran matematika tentang bangun ruang pada siswa kelas V SD Negeri 3 Tersobo tahun ajaran 2017/2018.

Kata Kunci: Pendekatan Saintifik, Media Model, Matematika.

\section{PENDAHULUAN}


Matematika merupakan salah satu disiplin ilmu yang memiliki objek abstrak dan harus dikaitkan dengan realitas melalui proses penalaran deduktif supaya dapat meningkatkan kemampuan berpikir logis dan memberikan kontribusi dalam penyelesaian masalah dalam kehidupan sehari-hari, serta memberikan dukungan dalam pengembangan ilmu pengetahuan dan teknologi. Menurut Badan Standar Nasional Pendidikan (2006: 148) menyebutkan bahwa, "Ruang lingkup Matematika pada satuan pendidikan SD/MI, meliputi aspek bilangan, geometri dan pengukuran, dan pengolahan data. Wahyudi (2015: 368) menjelaskan bahwa, bangun ruang yang dibentuk oleh daerah segi banyak yang disebut sisi.

Proses pembelajaran pada materi bangun ruang kelas V SD, sebaiknya siswa menemukan sendiri konsep dari bangun ruang. Oleh karena itu hendaknya guru dapat memilih pendekatan yang tepat pada saat pembelajaran.

Berdasarkan hasil observasi dan wawancara yang dilakukan pada tanggal 6 November 2017, diketahui proses pembelajaran Matematika di kelas V SDN 3 Tersobo kurang maksimal. Hal tersebut disebabkan oleh beberapa faktor, yaitu: guru kurang menggunakan media yang inovatif dan variatif untuk menunjang proses pembelajaran, siswa menjadi pasif karena pembelajaran terpusat pada guru. Hal ini menyebabkan pemahaman terhadap konsep-konsep Matematika masih rendah dan berdampak pada rata-rata nilai UTS Matematika siswa hanya mencapai 60,31 dengan KKM $=63$. Dari 39 siswa terdapat 19 siswa yang tuntas dan 20 siswa belum tuntas.

Berdasarkan uraian di atas, peneliti memilih solusi untuk meningkatkan pembelajaran yaitu dengan penerapan pendekatan saintifik.Pembelajaran menggunakan pendekatan saintifik membuat pembelajaran terpusat pada siswa dan guru hanya sebagai fasilitator serta memberikan kesempatan yang luas kepada siswa untuk terlibat aktif dalam pembelajaran.

Hosnan (2014: 34) mengemukakan, pengertian pendekatan saintifik adalah proses pembelajaran yang dirancang sedemikian rupa agar peserta didik secara aktif mengkontruk konsep, hukum atau prinsip melalui tahapan-tahapan mangamati, merumuskan masalah, mengajukan hipotesis, megumpulakan data, menganalisa data, dan menarik kesimpulan serta mengomunikasikannya kepada orang lain tentang apa yang telah ditemukan. Sani (2014: 50) mengatakan bahwa pendekatan saintifik berkaitan erat dengan metode saintifik. Metode saintifik (ilmiah) pada umumnya melibatkan kegiatan pengamatan atau observasi yang dibutuhkan untuk perumusan hipotesis atau mengumpulkan data.

Pembelajaran dengan menerapkan pendekatan saintifik akan berhasil secara maksimal apabila dilengkapi dengan penggunaan media yang tepat. Pembelajaran dengan menggunakan media model dapat membuat siswa lebih mudah memahami materi. Menurut Asyhar (2011: 56), menyatakan bahwa model dan prototype adalah benda tiruan dalam wujud tiga dimensi yang merupakan representasi atau pengganti dari benda yang sesungguhnya. Menurut Daryanto (2014: 30), menyatakan bahwa media tiruan atau sering disebut media model merupakan media tiga dimensi ialah sekelompok media tanpa proyeksi yang penyajiannya secara visual tiga dimensional. Anitah (2009: 146) mengemukapkan, pengertian model adalah media tiga dimesi yang mewakili benda sebenarnya.

Melalui penerapan pendekatan saintifik dengan media model diharapkan dapat meningkatkan pembelajaran Matematika tentang bangun ruang. 
Berdasarkan uraian di atas, peneliti memiliki keinginan untuk melaksanakan Penelitian Tindakan Kelas (PTK) dengan berkolaborasi dengan guru kelas V SDN 3 Tersobo, dengan judul "Penerapan Pendekatan Saintifik dengan Media Model dalam Peningkatan Pembelajaran Matematika tentang Bangun Ruang pada Siswa Kelas V SDN 3 Tersobo Tahun Ajaran 2017/2018."

Rumusan masalah dalam penelitian ini adalah: (1) bagaimana langkah-langkah penerapan pendekatan saintifik dengan media model dalam peningkatan pembelajaran Matematika tentang bangun ruang pada siswa kelas V SDN 3 Tersobo tahun ajaran 2017/2018?, (2) apakah penerapan pendekatan saintifik dengan media model dapat meningkatkan pembelajaran Matematika tentang bangun ruang pada siswa kelas $\mathrm{V}$ SDN 3 Tersobo tahun ajaran 2017/2018?, dan (3) apa kendala dan solusi dalam penerapan pendekatan saintifik dengan media model dalam peningkatan pembelajaran Matematika tentang bangun ruang pada siswa kelas $V$ SDN 3 Tersobo tahun ajaran $2017 / 2018 ?$.

Adapun tujuan dari penelitian ini yaitu: (1) Mendeskripsikan langkah-langkah dalam penerapan pendekatan saintifik dengan media model dalam peningkatan pembelajaran Matematika tentang bangun ruang pada siswa kelas V SDN 3 Tersobo tahun ajaran 2017/2018, (2) Meningkatkan pembelajaran Matematika tentang bangun ruang melalui penerapan pendekatan saintifik dengan media model pada siswa kelas $\mathrm{V}$ SDN 3 Tersobo tahun ajaran 2017/2018, (3) Mendeskripsikan kendala dan solusi dalam penerapan pendekatan saintifik dengan media model dalam peningkatan pembelajaran Matematika tentang bangun ruang pada siswa kelas V SDN 3 Tersobo tahun ajaran 2017/2018.

\section{METODE}

Penelitian ini merupakan penelitian tindakan kelas (PTK) yang dilakukan secara kolaboratif antara peneliti dan guru kelas V di SDN 3 Tersobo tahun ajaran 2017/2018. Subjek dalam penelitian ini siswa kelas V SD yang berjumlah 39 siswa.

Data yang digunakan pada penelitian ini adalah data kuantitatif dan data kualitatif. Sumber data pada penelitian ini yaitu guru, siswa dan dokumen. Teknik pengumpulan data yang digunakan yaitu teknik tes dan teknik nontes. Alat pengumpulan data pada penelitian ini, yaitu lembar tes, lembar observasi, dan pedoman wawancara. Teknik uji validitas data menggunakan triangulasi sumber dan triangulasi teknik. Adapun proses analisis data dalam penelitian ini sesuai dengan pendapat Miles dan Huberman (Sugiyono, 2015: 338-345) meliputi reduksi data, penyajian data, serta penarikan kesimpulan. Indikator kinerja penelitian baik dari segi proses oleh guru dan siswa maupun hasil pelaksanaan pembelajaran melalui penerapan pendekatan saintifik dengan media model sebesar 85\%. KKM hasil belajar yang ditargetkan yaitu 70 . Penelitian ini dilaksanakan dalam tiga siklus dan setiap siklusnya terdiri dari dua pertemuan. Tahapan dalam setiap siklus sesuai dengan model yang dikembangkan oleh Kurt Lewin (Arikunto, 2013: 131), yaitu:perencanaan,pelaksanaan, observasi, dan refleksi. 


\section{HASIL DAN PEMBAHASAN}

Pembelajaran Matematika tentang bangun ruang pada siswa keals V SD Negeri 3 Tersobo dilaksanakan sesuai dengan langkah-langkah penerapan pendekatan saintifik dengan media model yaitu: (1) mengamati dengan media model, (2) menanya dengan media model, (3) mencoba dengan media model, (4) menalar dengan media model, dan (5) mengkomunikasikan dengan media model.

Data hasil observasi terhadap guru dan siswa siklus I, II, dan III sebagai berikut:

Tabel 1. Hasil Observasi Penerapan Pendekatan Saintifik dengan Media Model terhadap Guru dan Siswa

\begin{tabular}{cll}
\hline \multirow{2}{*}{ Siklus } & \multicolumn{2}{c}{ Persentase } \\
\cline { 2 - 3 } & Guru & Siswa \\
\hline I & $86,50 \%$ & $86 \%$ \\
\hline II & $88,99 \%$ & $88,33 \%$ \\
\hline III & $92,16 \%$ & $90,99 \%$ \\
\hline
\end{tabular}

Berdasarkan data pada tabel 1, dapat diketahui hasil observasi guru pada siklus I $=86,50 \%$, siklus $\mathrm{II}=88,99 \%$ dan siklus $\mathrm{III}=92,16 \%$. Adapun respon atau aktivitaas siswa dalam penerapan pendeaktan saintifik dengan media model pada siklus I = 86\%, siklus II = 88,33\%, dan siklus III = 90,99\%. Hasil tersebut menunjukan bahwa penerapan pendekatan saintifik dengan media model yang dilakukan oleh guru dan siswa sudah mencapai indikator kinerja penelitian sebesaar $85 \%$.

Selanjutnya peningkatan ke-tuntasan hasil belajar siswa dapat dilihat pada tabel 2 di bawah ini.

Tabel 2 Hasil Belajar Siswa pada siklus I, II, dan III

\begin{tabular}{|c|c|c|c|}
\hline \multirow{3}{*}{ Siklus } & \multirow{3}{*}{$\begin{array}{c}\text { Rata- } \\
\text { rata } \\
\text { Nilai }\end{array}$} & \multicolumn{2}{|c|}{ Siswa } \\
\hline & & Tuntas & $\begin{array}{l}\text { Belum } \\
\text { Tuntas }\end{array}$ \\
\hline & & $\%$ & $\%$ \\
\hline I & 76,40 & 88,46 & 11,54 \\
\hline II & 77,62 & 92,30 & 7,70 \\
\hline III & 82,75 & 96,15 & 3,85 \\
\hline
\end{tabular}

Berdasarkan pada tabel 2 diatas, dapat diketahui bahwa rata-rata nilai siswa dan hasil bealjar siswa selalu mengamami peningkatan pada setiap siklus. Pada siklus I rata-rata nilai siswa $=76,40$ dengan persentase ketuntasan sebesar $88,46 \%$, siklus II rata-rata nilai siswa $=77,62$ dengan persentase $92,30 \%$, dan siklus III rata-rata nilai siswa $=82,75$ dengan persentase ketuntasan sebesar 96,15\%. Sedangkan jumlah siswa yang belum tuntas mengalami penurunan setiap siklus. Pada siklus I siswa yang belum mencapai $\mathrm{KKM}=11,54 \%$, siklus $\mathrm{II}=7,70 \%$, dan siklus $\mathrm{III}=3,85 \%$. 


\section{SIMPULAN}

Berdasarkan hasil penelitian dan pembahasan dapat disimpulkan bahwa: (1) penerapan pendeakatan saintifik dengan media model sudah dilaksanakan sesuai langkah-langkah yaitu mengamati dengan media model, menanya dengan media model, mencoba dengan media model, menalar dengan media model, dan mengkomunikasikan dengan media model, (2) penerapan pendekatan saintifik dengan media model dapat meningkatkan pembelajaran matematika tentang bangun ruang pada siswa kelas V SD Negeri 3 Tersobo Tahun Ajaran 2017/2018, hal ini dibuktikan dengan meningkatnya ketuntasan hasil belajar siswa, yaitu pada siklus I $=86 \%$, siklus II = 88,33\%, dan siklus III = 90,99\%, (3) kendala yang dihadapi yaitu: (a) siswa kurang reponsif terhadap pertanyaan yang diajukan guru, (b) siswa gaduh dan kurang memperhatikan apa yang disampaikan guru, (c) hanya beberapa siswa yang berani bertanya,(d) siswa masih kurang aktif dalam kegiatan mencoba,(e) siswa belum berani menanyakan apa yang dirasa kurang jelas. Berdasarkan kendala-kendala tersebut, maka diperoleh, yaitu: (a) mengingatkan guru untuk mengefektifkan waktu, (b) mengingatkan guru untuk memotivasi siswa untuk bertanya, (c) guru diingatkan untuk menegur siswa yang membuat kegaduhan.

Berdasarkan kesimpulan tersebut, adapun saran yang dapat disampaikan, yaitu: (1) guru, hendaknya melaksanakan pembelajaran sesuai alokasi waktu yang tepat, (2) siswa, lebih berani mengajukan pertanyaan dan pendapatnya, lebih focus dan aktif dalam mengikuti pembelajaran, (3) sekolah, sebaiknya sekolah mendukung dan memfasilitasi dalam melaksanakan pembelajaran yang inovatif, seperti pendekatan dan media pembelajaran, dan (4) peneliti, hendaknya peneliti mampu melakukan penelitian yang lebih baik dengan senantiasa mempelajari dan mengkaji penelitian terdahulu.

\section{DAFTAR PUSTAKA}

Anitah. (2009). Media Pembelajaran. Surakarta: UNS Press.

Arikunto, S. (2013). Dasar- dasar Evaluasi Pendidikan. Jakarta: Bumi Aksara

Asyhar, R. (2011). Kreatif Mengembangkan Media Pembelajaran. Jakarta: Gaung Persada Press Jakarta.

BSNP. (2006). Standar Isi untuk Satuan Pendidikan Dasar dan Menenga Standar Kompetensi dan Kompetensi Dasar SD/MI. Jakarta: Depdiknas

Daryanto. (2014). Pendekatan Pembelajaran Saintifik Kurikulum 2013. Yogyakarta: Gava Media

Hosnan. (2014). Pendekatan Saintifik dan Kontekstual dalam Pembelajaran Abad 21. Bogor: Ghalia Indonesia.

Sani, R. (2014). Pembelajaran Saintifik untuk Kuriulum 2013. Jakarta: Bumi Aksara.

Sugiyono. (2015). Memahami Penelitian Kualitatif. Bandung: Alfabeta.

Wahyudi.(2015). Panduan PembelajaranMatematika Sekolah Dasar.Surakarta: UNS Pressonal 